\title{
The Effect of Competency-Based Curricula on the Promotion of Social Values and Civic Education in the Pre-University Education: Case of Kosovo
}

\author{
Muhabere Maliqi \\ PhD Candidate, Department of Sociology, \\ Faculty of Philosophy, University of Prishtina, \\ Str. "George Bush", Nr.31, 10 ooo, \\ Pristina, Kosovo

\section{Agim Hyseni} \\ Professor, Department of Sociology, \\ Faculty of Philosophy, University of Prishtina, \\ Str. "George Bush", Nr.31, 10 ooo, \\ Pristina, Kosovo
}

DOI: https://doi.org/10.36941/jesr-2022-0056

\section{Abstract}

This study investigates teachers' understanding of the competency-based curriculum framework. In addition, it investigates teachers' opinions on the promotion of civic education and social values through the curricular framework, and what impediments teachers face in implementing the curriculum on the civic education subject. A questionnaire, including structured and open-ended questions, was developed and distributed to 318 teachers. Findings of this study indicated that the majority of teachers understand the curricular framework including core and subject curricula, related to civic education and social values. In addition, findings indicate there are inadequate textbooks and insufficient professional development and training of teachers. Findings also indicate that inappropriate infrastructure and adequate equipment have a negative effect on the implementation of competency-based curricula. Recommendations highlight the need for a revision of textbooks based on the curricular framework provisions and additional training of teachers on implementing the competency-based curriculum. In addition, there is a need for providing adequate working conditions for teachers. Recommendation for future research is to include other factors such as students' performance and outcomes of the educational process.

Keywords: competency-based education, civic competence, social values, textbooks

\section{Introduction}

Education as a social institution represents the place where students socialize and gain their academic knowledge, skills and socialize with social values and norms. Formal education exists in all countries worldwide, and its implementation usually consists of a predesigned formal curriculum. 
Competency-based education originated in the US in the 1960s, but only in the last decade, many countries throughout the world have endorsed it in their education system. This transition has been subject to many studies, taking into consideration the political, economic, and social differences that exist in different countries. Thus, the implementation of competency-based education has encountered obstacles in different countries, thus implying the need for further studies across different countries. Competency-based curricula have a set of competencies that they refer to as the "ability to use knowledge - understood broadly as encompassing information, understanding, skills, values, and attitudes - in specific contexts and to meet demands" (UNESCO, 2015). These competencies can be cross-curricular or in other cases only subject-related. Moreover, competencybased education is considered learner-centered, thus making a difficult and challenging transition from the previous content-based model to the competency-based model. The competencies set out in the national curriculum frameworks of different countries have some differences, which reflects the characteristics of each country. With the reforms in education in 2011, Kosovo has initiated competency-based education in 95 schools as a pilot project. In 2016, the revised curricular framework of pre-university education was formally approved (MEST, 2016).

One of the main objectives of the ministry of education is to achieve an education system, according to the international standards, which promotes democratic society and social values. In this regard, the law on pre-university education, at the purpose section states: "to prepare the pupil for a responsible life in the spirit of good understanding, peace, tolerance, gender equality and friendship with members of all communities" (OG, 2011). The curriculum framework for preuniversity education stipulates that the goals of educating youth will be achieved through the development of knowledge, skills, attitudes, and values required by a democratic society, (MEST, 2016, pg. 15) and the promotion of general cultural and social values (MEST, 2016, pg. 15).

The core curriculum regulates the organization and implementation of the curriculum within the levels of pre-university education based on the legal provisions set by the ministry of education. Thus, based on learning outcomes for competencies and for curricular areas at the curricular framework level, the core curriculum was prepared and structured. This basic document regulates the learning process, based on the curricular framework of Kosovo. It describes the learning outcomes for each key competence and learning area, according to curriculum levels, curriculum implementation methodologies, and student assessment.

Unlike core curriculum, the subject curriculum is prepared following the provisions set out in the core curriculum and the same contains learning outcomes that students should achieve within each subject and learning topic throughout a class and school year. In addition, it contains the methodological instructions and guidelines for the implementation of cross-curricular issues, didactic materials, and teaching resources.

The curricular framework of pre-university education in Kosovo contains six key competencies: (1) Communication and expression competence, (2) Thinking competence, (3) Learning competence, (4) Competence for life, work, and environment, (5) Personal competence and (6) Civic competence (MEST, 2016). The competencies set in the Kosovo curricular framework followed the recommendation of the European Parliament and of the Council on key competencies for lifelong learning (OJEU, 2006).

\section{Literature Review}

The use of the competence concept has old roots in the theory and practice curriculum field that can be traced back to the competency movement that started in the United States in the 196os-1970s and spread worldwide (Soare, 2015). Competency-based education was an effort to ensure students are prepared for postsecondary life with the skills they need to be successful (Bral, Cunningham, 2016). Competence-based education is defined as an "outcome-based approach to education that incorporates modes of instructional delivery and assessment efforts designed to evaluate mastery of learning by students through their demonstration of the knowledge, attitudes, values, skills, and 
behaviors required for the degree sought" (Gervais, 2016).

As stated in the recommendations of the European Parliament and of the Council, the competence of social and civic education covers all forms of behavior that equip individuals to participate in an effective and constructive way in social and working life, particularly in increasingly diverse societies (OJEU, 2006). In this regard, the importance of the promotion of civic education and social values for the youth generation is no doubt that has taken the attention of many scholars and policymakers. The importance of inclusion of social values and civic education in the education system is heavily supported (Karabel and Hasley, 1977; Naylor \& Diem, 1987; Schwartz, 1994; Aydin, 2005; Yıldırım, 2009; Cooper, 2014; Schwartz, 2017). The promotion of civic education and social values contributes to democratizing societies. In this context, the importance of the promotion of civic education and social values was given in many countries in the world as presented in the study from the International Association for the Evaluation of Educational Achievement-IEA (2021).

Schools are the most efficient institutions to teach human values to the next generations in the community. Students spend most of their lives in schools that allow schools to transfer predetermined values to the next generation and in general, teaching a set of values is needed for a democratic community to create desired habits and virtues of citizenship (Toker, 2021). In this context, teachers and their students will construct a community where social values will be the core of a democratic society.

Curriculum implementation refers to how teachers deliver instruction and assessment by using specified resources provided in a curriculum (Nevenglosky et al, 2019). Thus, the teaching process is of crucial importance, and how teachers structures learning, is key to the competence-based model (Gervais, 2016). Teachers with their knowledge and experience translate the structured curriculum into learning experiences, where students can acquire knowledge, skills, values, and attitudes. Civic education teachers should be knowledgeable of the competencies, which learners should acquire in order for them to teach and implement outcomes-based curriculum effectively (Kaumba et al, 2020). In addition to understanding the competency-based curriculum, teachers are required to interpret the curriculum correctly in the classroom so that they can foster civic competencies among students. Apart from the curriculum framework, textbooks represent another crucial resource that teachers need in teaching their students. Textbooks, especially at the primary level should have pictures and illustrative stories written from a child's perspective to elicit opinions and potential action (Petteri \& Mikko 2021).

Different factors, as observed by many authors in different countries, may impede the successful implementation of competency-based education. Insufficient training and guidance for curriculum implementation hindered accurate delivery to students (Nevenglosky et al, 2019). Effective training of teachers is crucial for the effective implementation of a curriculum, and before the implementation of any new change, teachers should attend training for updating them according to new curriculum demands (Daniel, 2020). In this context, more efforts should be spend to ensure well-prepared teachers by providing training at the level of the school (Bader \& Hamada, 2015) and ensuring adequate working conditions. Another common finding of studies from a wide range of school subjects and in a number of countries is that textbook tasks fail to meet the demands set in the curriculum and the recommendations of educational research (Jonas \& Emilia, 2021).

\section{Research Methodology}

The descriptive analysis method was used to analyze the curricular framework of Kosovo and its coherence with the key competencies for long life learning presented in the recommendations of European Parliament and of the Council. In addition, to achieve the objectives of this study, a mix of quantitative and qualitative methods is used. A questionnaire was prepared with structured questions for the collection of quantitative data and open-ended questions for the collection of the qualitative data from the respondents for the issues related to the research questions. The questionnaire was developed and designated for the teachers of civic education subjects. 
The structure of the questionnaire was divided into three main sections: the first section consisted of general questions including age, school location, gender, educational qualification, area of qualification, and working experience. The second section consisted of eight questions regarding teachers' opinions if the competence-based curricula promote social values and civic education, and about the factors that influence the implementation of the curricula. The third part included additional open-ended questions to receive more information from the respondents, regarding the competency-based education for civic competence and factors influencing the implementation of the curriculum framework.

\subsection{Objectives of this study}

This paper aims to highlight the reforms of the curricular framework based on competencies and to analyze the teacher's stand on the competency-based curricula. Moreover, this study aims to gain results whether the teachers' view is affirmative whether competency-based curriculum framework, promotes civic education and social values. In addition, this paper tackles also the impediments that teachers face on the implementation of the competency-based curriculum.

\subsection{The research questions}

This study focuses on two research questions:

1. How do teachers' perceive the curricular framework based on competencies, and more specifically, how are civic education and social values promoted through the competencebased curriculum?

2. What impediments do teachers face in the implementation of the curriculum framework specifically regarding civic competence?

\subsection{Data collection}

The questionnaire was physically disseminated to teachers for the purpose of data collection. The questionnaire was prepared based on the Likert five-scale model, which is a valid tool in measuring the opinions of the respondents. Subsequently, all respondents who participated in this study were informed about the research objectives and the confidentiality of the data. The questionnaire designed for teachers of civic education was prepared and disseminated to teachers in primary and high schools in Kosovo. From the total number of 542 teachers of civic education subjects, 348 of them have been selected for this study, using the random sample method. The data were analyzed statistically using SPSS version 21.

\section{Analysis and Results}

In order to reach the objectives of the study and gain answers for the two research questions, the developed questionnaire was distributed to the teachers of civic education. The questionnaire was distributed to 348 teachers representing 64 percent of the overall number of 542 teachers of civic education. Regarding the location, 153 teachers or 43.97 percent belong to schools in urban areas, while 195 or 56.03 percent belong to schools in rural areas.

Regarding the academic qualification of respondents, the variable is divided into four categories. From the results presented in table 1, we can observe that 7 teachers have finished high school, 134 have Bachelor's degrees, 122 have finished undergraduate studies (4-year system) and 84 have Master's degrees. From 348 respondents, one answer is missing regarding the teacher's academic qualification. 
Table 1:

\begin{tabular}{|l|c|c|}
\hline Teachers academic qualification & Frequency & Percentage \\
\hline High school & 7 & 2.01 \\
\hline Bachelor & 134 & 38.51 \\
\hline 4y undergraduate studies & 122 & 35.06 \\
\hline Master & 84 & 24.14 \\
\hline missing system & 1 & 0.29 \\
\hline Total & 348 & 99.71 \\
\hline
\end{tabular}

Source: authors calculations

In the question for the field of academic qualification of teachers, as per the result in table 2, only 47 teachers, or 13.51 percent have a degree from the field of civic education. On the other hand, 139 have a degree in the field of History and Civic Education and 63 have their degree in the program of Geography and Civic Education. From the data presented, a large number of teachers do not have the appropriate field of academic qualification for civic education. The reforms done in the curriculum framework have not been able to overcome obstacles in this process since there were other academic qualifications programs in the universities in Kosovo, and only recently new programs are included in universities specifically in the field of civic education. Out of 348 respondents, 16 teachers have 1-2 years of experience, 103 teachers have 3-7 years of experience, and 122 teachers have more than 8 years of experience. This indicates that more experienced staff have attended previous programs in the universities. Thus, the need for improvement is apparent.

\section{Table 2:}

\begin{tabular}{|l|c|c|}
\hline Field of academic qualification of teachers & Frequency & Percentage \\
\hline Civic education & 47 & 13.51 \\
\hline History and civic education & 139 & 39.94 \\
\hline Geography and civic education & 63 & 18.10 \\
\hline Other & 99 & 28.45 \\
\hline Total & 348 & 100.00 \\
\hline
\end{tabular}

Source: authors calculations

The next part of this paper, analysis the effect on the promotion of civic education and social values through the curricular framework, core curricula, and the subject curricula. In addition, this part includes questions for the textbooks in use. Moreover, whether textbooks are prepared in accordance and based on the competency-based curricular framework. For this purpose, eight questions have been set on the questionnaire dedicated to the teachers of civic education.

On the question, if the new competency-based education curriculum is clear and understandable for teachers, the results in table 3 showed that 62.93 percent of teachers agree that the new curricular framework is clear and understandable and 7.47 percent fully agree. Around 18.68 percent of the total number of respondents were neutral regarding this question while only 9.77 percent disagree and totally disagree.

Table 3:

\begin{tabular}{|l|c|c|}
\hline The competency-based curriculum is clear and understandable & Frequency & Percentage \\
\hline Totally agree & 26 & 7.47 \\
\hline Agree & 219 & 62.93 \\
\hline Neutral & 65 & 18.68 \\
\hline
\end{tabular}




\begin{tabular}{|l|c|c|}
\hline The competency-based curriculum is clear and understandable & Frequency & Percentage \\
\hline Disagree & 30 & 8.62 \\
\hline Totally disagree & 4 & 1.15 \\
\hline Missing system & 4 & 1.15 \\
\hline Total & 348 & 100.00 \\
\hline
\end{tabular}

Source: authors calculations

On the question of whether the Curriculum Framework of the pre-university education system has clear expectations and guidelines for promoting and developing knowledge on civic education and social values, results showed that 64.94 percent of teachers agree and 6.32 percent strongly agree. As shown in table 5, only 9.7 percent of respondents disagree and $1.1 \%$ strongly disagree, thus implying that the curriculum framework promotes civic education and social values.

Table 4:

\begin{tabular}{|l|c|c|}
\hline $\begin{array}{l}\text { The curriculum framework has clear expectations and guidelines for promoting } \\
\text { and developing knowledge of civic education and social values. }\end{array}$ & Frequency & Percentage \\
\hline Totally agree & 22 & 6.32 \\
\hline Agree & 226 & 64.94 \\
\hline Neutral & 62 & 17.82 \\
\hline Disagree & 34 & 9.77 \\
\hline Totally disagree & 4 & 1.15 \\
\hline Total & 348 & 100.00 \\
\hline
\end{tabular}

Source: authors calculations

The results of the questionnaire indicated that 65.8 percent of the teachers agree that the core curriculum had a positive effect on the promotion of civic education and social values, while only $5 \cdot 75$ percent of respondents disagree or totally disagree.

Table 5:

\begin{tabular}{|l|c|c|}
\hline $\begin{array}{l}\text { The core curricula have clear expectations and guidelines for promoting and } \\
\text { developing knowledge of civic education and social values. }\end{array}$ & Frequency & Percentage \\
\hline Totally agree & 31 & 8.91 \\
\hline Agree & 229 & 65.80 \\
\hline Neutral & 68 & 19.54 \\
\hline Disagree & 15 & 4.31 \\
\hline Totally disagree & 5 & 1.44 \\
\hline Total & 348 & 100.00 \\
\hline
\end{tabular}

Source: authors calculations

As for the question used for determining the promotion of civic education and social values through the subject curricula of civic education, the teachers were asked, if the civic education subject curricula have clear expectations and guidelines for the promotion and development of knowledge about social values. As per the results presented, 63.22 percent of teachers agree that the civic education subject curriculum improves the promotion of civic education and social values in the preuniversity education system. Since there are a small number of respondents, who disagree, the teacher's majority opinion is that the subject curricula significantly promotes the social values based on the curriculum framework. 
Table 6:

\begin{tabular}{|l|c|c|}
\hline $\begin{array}{l}\text { Civic education subject curricula, in the classes in which I work, have clear expectations } \\
\text { and guidelines for promoting and developing knowledge of civic education and social } \\
\text { values. }\end{array}$ & Frequency & Percentage \\
\hline Totally agree & 32 & 9.20 \\
\hline Agree & 220 & 63.22 \\
\hline Neutral & 66 & 18.97 \\
\hline Disagree & 23 & 6.61 \\
\hline Totally disagree & 7 & 2.01 \\
\hline Total & 348 & 100.00 \\
\hline
\end{tabular}

Source: authors calculations

In line with the aim of the paper, the promotion of social values is an important part of the competency-based curricula and for civic competence in particular. Hence, the adequate promotion of social values constitutes a challenge in reaching the objectives for a democratic society. As presented in table 7 , the respondents mostly agree that the curricular framework promotes social values. Moreover, the results indicate that 211 teachers agree that the curricular framework promotes human rights while 37 disagree. From 348 respondents, 202 teachers agree that democracy is promoted in the curriculum framework, while 47 respondents disagree. In addition, almost 200 teachers agree that multiculturalism and religious tolerance are promoted while only 146 teachers agree that gender equality is promoted through the curriculum framework. Regarding gender equality, 87 teachers disagree and 33 totally disagree that gender equality is promoted in the curriculum framework. Hence, this finding constitutes the highest number of teachers who consider that gender equality is not sufficiently promoted in the curricular framework.

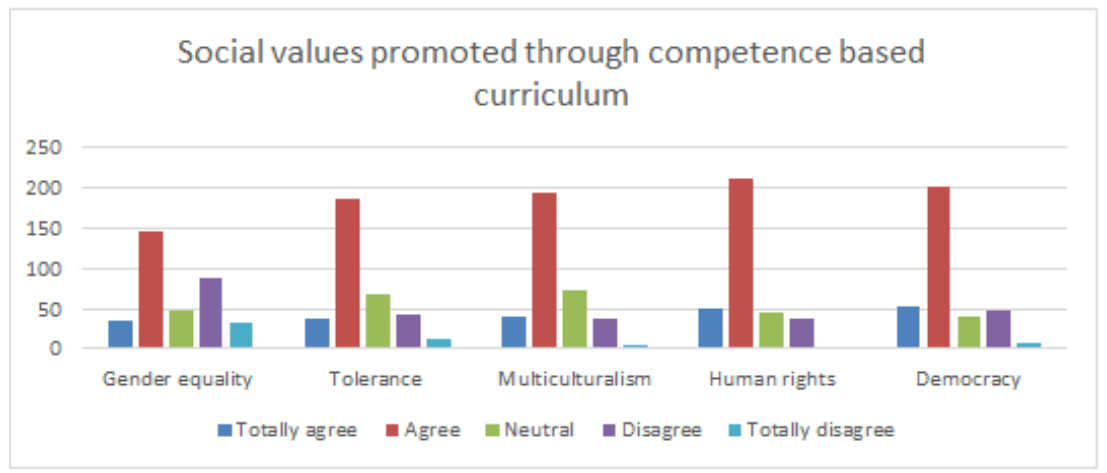

Chart 1:

Source: authors calculations.

Regarding the question on the promotion of social values through the textbooks of the civic education subject, 103 teachers claimed that the textbooks on civic education have topics and learning units related to the curriculum requirements for promoting social values to students, while 92 disagree and 81 totally disagree. In addition, 52 teachers were neutral regarding this question, thus implying that the majority of teachers consider the textbooks do not contain learning material, which adequately promotes the social values based on the curriculum framework. Even though there is significant deviance of the opinion of the respondents, still the majority of them consider the textbooks as not adequately related to the curriculum regarding the promotion of social values. 
Table 7:

\begin{tabular}{|l|c|c|}
\hline $\begin{array}{l}\text { Civic Education textbooks, in the classrooms in which I work, have topics and } \\
\text { learning units related to the requirements of the curriculum for the promotion of } \\
\text { civic education and social values to students. }\end{array}$ & Frequency & Percentage \\
\hline Totally agree & 20 & 5.75 \\
\hline Agree & 103 & 29.60 \\
\hline Neutral & 52 & 14.94 \\
\hline Disagree & 92 & 26.44 \\
\hline Totally disagree & 81 & 23.28 \\
\hline Total & 348 & 100.00 \\
\hline
\end{tabular}

Source: authors calculations

Furthermore, regarding the question, if the textbooks have illustrations and other graphic representations to promote social values to students, 97 of teachers agree while 118 disagree. Similar to the previous question, regarding the textbooks, there is a majority of respondents who consider that textbooks do not contain necessary illustrations and graphic materials which could enable more effective teaching of social values to students. As per table 11, the data show that in total more than $52 \%$ of respondents do not agree and totally disagree that textbooks have appropriate graphic materials based on the curriculum framework for the promotion of social values.

Table 8:

\begin{tabular}{|l|c|c|}
\hline $\begin{array}{l}\text { Civic Education textbooks, in the classes I work, have illustrations and other } \\
\text { graphic representations to promote social values to students. }\end{array}$ & Frequency & Percentage \\
\hline Totally agree & 17 & 4.89 \\
\hline Agree & 97 & 27.87 \\
\hline Neutral & 49 & 14.08 \\
\hline Disagree & 118 & 33.91 \\
\hline Totally disagree & 65 & 18.68 \\
\hline Missing data & 2 & 0.57 \\
\hline Total & 348 & 100.00 \\
\hline
\end{tabular}

Source: authors calculations

Referring to the question of whether the implementation of the new curriculum is difficult to implement due to non-fulfillment of conditions (infrastructure, equipment, etc.), the results showed that 41.8 percent of teachers agree and 42.1 percent fully agree that the implementation of the new curriculum is difficult to implement. In this context, there is an overall opinion that infrastructure poses a major challenge to the successful implementation of the competency-based curriculum.

\section{Table 9:}

\begin{tabular}{|l|c|c|}
\hline $\begin{array}{l}\text { The implementation of the new curriculum is difficult to implement due to non- } \\
\text { fulfillment of conditions (infrastructure, equipment, etc.) }\end{array}$ & Frequency & Percentage \\
\hline Totally agree & 147 & 42.24 \\
\hline Agree & 146 & 41.95 \\
\hline Neutral & 24 & 6.90 \\
\hline Disagree & 27 & 7.76 \\
\hline Totally disagree & 4 & 1.15 \\
\hline Total & 348 & 100.00 \\
\hline
\end{tabular}

Source: authors calculations 
The next part of this paper includes the respondent's opinions for the open questions of the questionnaire, through which teachers could express other challenges on the implementation of the curriculum framework, textbooks of the subject of civic education, and the preparation which was conducted for the initiation of competency-based education. Related to the implementation of the curriculum in practice, its requirements based on the promotion of civic education and social values, most of the teachers mentioned lack of adequate textbooks and other didactic materials for the subject of civic education which are not in line with the implementation of the subject curriculum of civic education competence. In addition, on the question, if they have participated in training for the implementation of the new curricular framework, almost all the teachers have attended training but have pointed out that the training attended was for a short period of time and did not provide more detailed guidance on the implementation of the new curricular framework.

\section{Discussions}

Based on the results attained through questionnaires, we can conclude that the majority of teachers of civic education understand the competency-based education curriculum. However, findings indicate that around ten percent of the teachers claimed they do not agree that curricular framework, core curricula, and subject curricula do promote adequately civic education and social values. Other factors that impede the successful implementation of competency-based education, primarily with insufficient training of teachers with the new curriculum may correlate with these findings. The findings of this study relate to other studies which concluded that is important that teachers are trained on conveying values to students (Keskin et al, 2014). Regarding the social values promoted through the competence-based curricula, findings suggest that in teachers' opinion, most promoted values through the curricular framework are human rights, democracy, and the last gender equality. In a study conducted in Turkey (Toker, 2021), findings indicated that there are different opinions on the values that ought to be taught to students and may be subject to the specific countries' cultures. However, social values that promote a democratic society are part of the curriculum of many countries in the world as can be noted from the study done on twenty-eight countries (Purta et al, 2001).

Textbooks are a crucial component for the successful implementation of competency-based education for civic education. In teachers' opinion, the textbooks are not in line with the curriculum framework and do not provide adequate resources and learning material for teaching civic education. In addition, the majority of teachers agree that textbooks do not have adequate illustrations and graphic material that teachers could use in teaching students. This finding is similar to other studies in different countries, which concluded that there is a lack of adequate and appropriate textbooks (Makunja, 2016; Wambua \& Waweru, 2019). These results are consistent with other previous studies, which have shown that textbook tasks are rarely in line with the current curriculum, resulting in discrepancies between the textbooks and the national curriculum. (Jonas \& Emilia, 2021). Furthermore, as stated by Petteri \& Mikko (2021), the social studies textbooks fall short of the goals of the national curriculum. Curricula and textbooks express rather disparate expectations about students' civic learning (Arensmeier, 2018).

One notable finding in the study is that civic education teachers have received insufficient training for the implementation of the competence-based curriculum. The training was too short in time and did not cover all themes as foreseen in the curricular framework. Thus, findings indicate a clear need for training for in-service teachers for competency-based education. Very limited or complete lack of training for teachers has been observed and concluded in other studies as well (Komba and Mwandaji, 2015; Serdenciuc, 2013; Kabombwe, \& Mulenga, 2019; Lumadi, 2014; Daniel, 2020). The lack of training is likely to affect teachers' competency in implementing the current curriculum (Ngeno \& Mwoma, 2021). In many countries where competency-based education was endorsed, it lacked proper preparations for its implementation, including training of in-service teachers. In addition, the results of this study indicate that more than eighty percent of the teachers 
claim that inappropriate infrastructure and lack of equipment affect their work in the implementation of the new curriculum. Inappropriate infrastructure and insufficient equipment are factors that teachers identify as impediments to the implementation of the competence-based curriculum, as observed also in other studies (Wambua \& Waweru, 2019). Thus, in many countries, there is still a need for improving the infrastructure of schools and the provision of adequate equipment and other learning materials.

\section{Conclusions and Recommendations}

This study aimed to investigate if the teachers of civic education understand the competence-based curricula specifically for civic competence and the challenges faced in implementation. In addition, the second objective was to investigate the promotion of civic education and social values through the curricular framework based on competencies in core curricula, subject curricula, and textbooks on civic education subjects. Thus, to identify factors that influence the implementation of the new curricular framework based on competencies and identify which factors pose impediments and need to be addressed accordingly. A questionnaire dedicated to the teachers of civic education in preuniversity education has been developed and distributed for data collection. From approximately 543 teachers of civic education subjects, 348 participated in this study.

The findings imply that teachers overall understand the competency-based curricula and they endorse the statement that the curricular framework promotes civic education and social values. In addition, the findings of the study conclude that textbooks in use need a revision since they lack compliance with the curriculum provisions and thus pose an impediment in implementing the competence of civic education. Furthermore, teachers have identified inadequate infrastructural capacities and insufficient equipment as challenges for their work. Based on the results of the analysis and findings, in order to improve the effective promotion of civic education and social values based on the curricular framework, the recommendations are the following:

- To address the lack of adequate textbooks of civic education subject, ensuring that they are prepared based on the curricular framework for civic competence and promoted social values.

- Improving the working conditions of teachers and providing adequate tools and equipment for the successful implementation of the civic competence curriculum.

- Provision of additional training for teachers regarding the implementation of the curriculum framework.

With the intention to improve the implementation of the curriculum framework, further studies on the issue are highly recommended. Especially by including other factors such as the students' performance and the outcomes of the educational process, which could provide more findings. Thus, identifying more factors that are relevant for the successful implementation of competency-based education.

\section{References}

Arensmeier, C. (2018). Different Expectations in Civic Education: A Comparison of Upper-Secondary School Textbooks in Sweden. Journal of Social Science Education, 17(2):5-20. Retrieved from http://oru.divaportal.org/smash/get/diva2:1241969/FULLTEXTo1.pdf

Aydın, M. Z. (2005). Ailede çocuğun ahlak eğitimi. İstanbul: DEM Yayınları.

Bader, F., \& Hamada, H. (2015). Competency Based Approach Between Theory And Practice. Sciences Humaines, No. 44, 7-19. Retrieved from https://www.researchgate.net/publication/334830845_Competency _Based_Approach_Between_Theory_And_Practice

Bral, C. \& Cunningham, J. (2016). Foundations of quality in competency-based programs: Competencies and assessments. Journal of Competency Based-Education, 1(3): 118-121. Retrieved from https://onlinelibrary.wiley.com/doi/epdf/10.1002/cbe2.1027 
Cooper, D. (2014). Character education: a study of an elementary school leadership academy. (Doctoral Thesis), Wilmington University, USA.

Kosia Mokoro, D. (2020). Perception of Teachers on their Preparedness for Implementation of the Competencebased Curriculum among Secondary Schools in Arumeru District, Tanzania. East African Journal of Education and Social Sciences, 1(2), 109-117. Retrieved from https://eajess.ac.tz/wpcontent/uploads/2020/12/EAJESS-1-2-0026-updated.pdf

Gervais, J. (2016). The operational definition of competency-based education. The Journal of Competency-Based Education, 1(2), 98-106. https://doi.org/10.1002/cbe2.1011

Bakken, J., \& Andersson-Bakken, E. (2021). The textbook task as a genre, Journal of Curriculum Studies, 53(6), 729748, https://doi.org/10.108o/oo220272.2021.1929499

Kabombwe, Yvonne Malambo, \& Mulenga, Innocent Mutale. (2019). Implementation of the competency-based curriculum by teachers of History in selected Secondary Schools in Lusaka district, Zambia. Yesterday and Today, 22, 19-41. Retrieved from http://www.scielo.org.za/scielo.php?script=sci_arttext\&pid=S222303862019000200003

Kaumba, Chivunda \& Kabombwe, Yvonne \& Mwanza, Christine. (2020) Civic Competences: What does an Outcomes Based Curriculum mean for a Civic Education Teacher in Zambia? International Journal of Education and Research. 8(6): 87-104. Retrieved from https://www.researchgate.net/publication/342770820_ Civic_Competences_What_does_an_Outcomes_Based_Curriculum_mean_for_a_Civic_Education_Teacher_ in_Zambia

Karabel, J., \& Halsey, A. (1977). Educational Research: A Review and an Interpretation. In Power and Ideology in Education. New York: Oxford University Press.

Keskin, Yusuf \& Keskin, Sevgi Coşkun \& Söylemez, Hatice. (2014). Phenomenological study of social studies teachers and values education in Turkey. Procedia - Social and Behavioural Sciences, 116, 4526-4531. https://doi.org/10.1016/j.sbspro.2014.01.979

Komba, Sotco Claudius \& Mwandanji, Marcus. (2015). Reflections on the Implementation of Competence Based Curriculum in Tanzanian Secondary Schools. Journal of Education and Learning, 4(2), 73-80. Retrieved from https://files.eric.ed.gov/fulltext/EJ1075171.pdf

Lumadi, Walter Mutendwahothe. (2014). Exploring Factors Faced by Teachers in Curriculum Implementation. Mediterranean Journal of Social Sciences, 5(6). https://doi.org/10.5901/mjss.2014.v5n6p171

Malak, M. B. \& Purta, T. J. (Eds). (2021). Influences of the IEA Civic and Citizenship Education Studies, Springer. https://link.springer.com/content/pdf/10.1007\%2F978-3-030-71102-3.pdf

Makunja, Grace. (2016). Challenges Facing Teachers in Implementing Competence-Based Curriculum in Tanzania: The Case of Community Secondary Schools in Morogoro Municipality. International Journal of Education and Social Science. 3(5), 30-37. Retrieved from https://www.academia.edu/28976937/Challenges_Facing _Teachers_in_Implementing_Competence-based_Curriculum_in_Tanzania_The_Case_of_Community_Seco ndary_Schools_in_Morogoro_Municipality

Ministry of Education Science and Technology (MEST). (2016). Curricular framework of pre-university education in Kosovo. Retrieved from https://masht.rks-gov.net/uploads/2017/03/korniza-kurrikulare-finale.pdf

Naylor, D.T. \& Diem, R.A. (1987). Elementary and middle school social studies. New York: Random House.

Nevenglosky, E. A. \& Cale, C \& Aguilar, P. S. (2019). Barriers to effective curriculum implementation. Research in Higher Education Journal, 36. Retrieved from https://files.eric.ed.gov/fulltext/EJ1203958.pdf

Ngeno, B., Mweru, M. \& Mwoma, T. (2021). Availability of Physical Infrastructure in Implementation of the Competence-Based Curriculum in Public Primary Schools in Kericho County. East African Journal of Education Studies, 3(1), 130-146. https://doi.org/10.37284/eajes.3.1.344

Official Gazette (OG), (2011). Law No.04/L-032 on pre-university education in the Republic of Kosovo. Retrieved from https://gzk.rks-gov.net/ActDocumentDetail.aspx?ActID=2770

Official Journal of the European Union (OJEU). 2006. Recommendation of the European Parliament and of the Council, of 18 December 2006 on key competences for lifelong learning (2006/962/EC). Retrieved from http://eur-lex.europa.eu/LexUriServ/LexUriServ.do?uri=OJ:L:2006:394:0010:0018:en:PDF

Petteri, Hansen \& Mikko, Puustinen. (2021). Rethinking society and knowledge in Finnish social studies textbooks. Journal of Curriculum Studies, 53(6), 857-873, https://doi.org/10.108o/o0220272.2021.1881169

Purta, T. J. \& Lehmann, R. \& Oswald, H. \& Schulz, W. (Eds.). (2001). Citizenship and Education in Twenty-eight Countries: Civic Knowledge and Engagement at Age Fourteen. The International Association for the Evaluation of Educational Achievement-IEA https://www.iea.nl/sites/default/files/2019-04/CIVED_Phase2_Age_Fourteen.pdf

Serdenciuc, L. Nadia. (2013). Competency-based education - implications on teachers' training. Procedia - Social and Behavioural Science, 76,754-758. Retrieved from https://cyberlinka.org/article/n/1073507/viewer 
Schwartz, S.H. (1994). Are there universal aspects in the structure and content of human values? Journal of Social Issues, 50(4), 19-45. Retrieved from https://www.researchgate.net/publication/227762767_Are_There_Universal_Aspects_in_the_Structure_and_Contents_of_Human_Values

Schwartz, S. H. (2017). The refined theory of basic values. In Roccas, S., Sagiv, L. (Eds.), Values and behavior: Taking a cross-cultural perspective (pp. 5172). Springer. Retrieved from https://www.researchgate.net/pub lication/306432422_The_Refined_Theory_of_Basic_Values

Soare, Emanuel. (2015). Perspectives on designing the competence based curriculum. Procedia - Social and Behavioral Sciences, 18o, 972-977. Retrieved from https://www.researchgate.net/publication/277934809_ Perspectives_on_Designing_the_Competence_Based_Curriculum

Toker, Gökçe A. (2021). Core Values in Education from the Perspective of Future Educators. Sage Open, 11 (2). https://doi.org/10.1177/21582440211014485

United Nations Educational, Scientific and Cultural Organization (UNESCO). (2015). Rethinking Education, towards a global common good. Retrieved from http://unesdoc.unesco.org/images/oo23/o02325/232555e.pdf

Wambua, M. E., \& Waweru, S. N. (2019). Constraints Facing Successful Implementation of the Competency-Based Curriculum in Kenya. American Journal of Educational Research, 7(12), 943-947. Retrieved from http://pubs.sciepub.com/education/7/12/8/.

Yıldırım, K. (2009). Values education experiences of Turkish class teachers: a phenomenological approach. Eurasian Journal of Educational Research, 35, 165-184. Retrieved from https://www.researchgate.net/publication/299133857_Values_Education_Experiences_of_Turkish_Class_Tea chers_A_Phenomonological_Approach 